\title{
Understanding the attitude of multidisciplinary teams working in leprosy
}

\author{
R. PREMKUMAR*, K. SATISH KUMAR* \& S. L. DAVE† \\ ${ }^{*}$ c/o Schieffelin Le prosy Research \& Training Centre, Karigiri, 632 \\ 106, N.A.A. Dist., India; †Nagpur University, Nagpur, India
}

\section{Accepted for publication 20 August 1993}

Summary This study investigated the attitude of health personnel who were working for the National Leprosy Eradication Programme (NLEP) in India to their leprosy patients. These personnel were studied individually and as homogeneous groups so that comparisons were possible within and among the groups, and between the groups in different regions who were conducting similar health programmes, with a difference in length of between 1 and 5 years.

The sample population was the NLEP employees of 2 state governments, consisting of 8 health professional groups. A questionnaire was developed for each of these groups to elicit information on 5 aspects of the relationships with their patients.

The main outcome of the study was that two-thirds of the personnel tested possessed the 'minimum desirable' interaction with their patients. The quality of their relationships differed only among work specialities, but was consistent within the same speciality in different regions; this pattern was unchanged af ter 5 years of a multidrug (MDT) programme. A further analysis showed that although they possessed a caring attitude towards patients from low socioeconomic classes, a domineering attitude towards these same patients was also prevalent. Analysis according to speciality revealed that laboratory technicians had the highest 'desirable attitude' $(74 \cdot 67 \%)$ and health educators had the lowest $(57 \cdot 5 \%)$, while the rest of the team members fell in between. The stigma shown towards leprosy was higher among doctors when compared to the rest of the team members.

Discussion is based on the performance, overall and in each of its 5 facets, of each the professional groups with reference to their job descriptions and with similar studies undertaken earlier.

\section{Introduction}

A brief survey of relevant literature shows that the stigma attached to leprosy and the discrimination against those suffering from it have been well documented. ${ }^{1-4}$ Bijlevd and his research team at the Royal Tropical Institute in Amsterdam ${ }^{1,5-7}$ and Kumar and his team at CLTRI, India ${ }^{8-10}$ have done extensive studies on the expectations of leprosy patients of medical teams in Indonesia, Kenya and India. In recent years tremendous 
advances have been made in understanding leprosy. Our own investigations have shown that leprosy health professionals in India have appreciated these advances and are equipped with adequate knowledge. ${ }^{11}$ Therefore it is reasonable to expect them to be free from discriminatory bias. A study of the attitudes of paramedical workers in leprosy concluded that a good working environment and job accomplishments are essential for an appropriate attitude towards leprosy patients. ${ }^{12}$ A study of Nigerian nurses has shown that because they knew little about leprosy they had an aversion to sufferers of this disease. ${ }^{13}$ The National Leprosy Eradication Programme in India (NLEP) is a nationwide programme, employing 24,474 people (in 1987). ${ }^{14}$ At district level it is organized into Leprosy Control Units (LCUs), Survey-Education-Treatment Centres (SETs) and Temporary Hospitalization wards. The NLEP is wholly funded by the Government of India and all aspects of care are given free to patients. Health personnel of the NLEP routinely undertake case finding, diagnosis, treatment, health education and rehabilitation.

A brief account of the whole survey in which the analysis of 'the attitude of the multidisciplinary teams to leprosy patients', is a part, is as follows: In 1987, the working environment of the NLEP personnel was investigated. A questionnaire was developed for this purpose which tested 4 major variables, (1) organizational behaviour, (2) human relations, (3) job satisfaction and (4) higher orders need strength. These were further subdivided into 19 variables (Table 2). (Details on most of these variables have been published already ${ }^{15-17}$ and are also in the process of publication. ${ }^{11,18}$ In this paper an attempt has been made to elaborate only the 'health team-leprosy patients relationship' which was one of the variables tested (no. 17 in Table 2), and, at the same time, to correlate it with a few of the other 18 variables in this survey.

This variable was chosen because the establishment of a close rapport with the patient and counselling are essential features of the NLEP work. Therefore attitudes of the personnel involved while directly dealing with leprosy patients affects the quality of the care given, and ultimately the efficacy of the programme itself. ${ }^{19}$

\section{OBJECTIVES OF THIS STUDY ARE AS FOLLOWS:}

1 to investigate the attitude to leprosy patients of the health personnel of the NLEP, as homogeneous groups;

2 to compare attitudes within and among the groups; and

3 to investigate whether attitudes changed as the programme evolved in 2 different regions while conducting similar programmes.

\section{Personnel and methods}

\section{PERSONNEL STUDIED}

We studied health professionals employed in the NLEP in India. For uniform data collection and adequate representation, cluster sampling was done. We chose 2 districts as clusters, 1 from Andhra Pradesh (AP) state and another from Tamil Nadu (TN) state; all health personnel working in the NLEP of both these districts were included in the study. These 2 districts were chosen because in one the MDT programme had started only 1 year before the data collection of this study, whereas in the other, the MDT had been in 
Table 1. Demographic details of the personnel participated in the study

\begin{tabular}{|c|c|c|c|c|c|c|c|c|}
\hline \multirow{2}{*}{$\begin{array}{l}\text { Health } \\
\text { personnel } \\
\text { numbers }\end{array}$} & \multirow{2}{*}{$\begin{array}{l}\text { No. of } \\
\text { posts }\end{array}$} & \multirow{2}{*}{$\begin{array}{c}\text { No. } \\
\text { participated } \\
\text { in study }\end{array}$} & \multicolumn{2}{|c|}{$\begin{array}{l}\text { State they } \\
\text { belong to }\end{array}$} & \multirow{2}{*}{$\begin{array}{l}\text { Mean age } \\
\text { range } \\
\text { (in years) }\end{array}$} & \multicolumn{2}{|c|}{ Sex } & \multirow{2}{*}{$\begin{array}{l}\text { Response } \\
\text { rate in } \%\end{array}$} \\
\hline & & & AP & $\mathrm{TN}$ & & $\mathbf{M}$ & $\mathrm{F}$ & \\
\hline 1 Doctor & 22 & 21 & 5 & 16 & $42(5 / 6)$ & 21 & 0 & $98 \cdot 4$ \\
\hline 2 Nurses & 23 & 23 & 8 & 15 & $36(1 / 2)$ & 0 & 23 & 100 \\
\hline 3 LTs & 15 & 15 & 4 & 11 & $32(1 / 3)$ & 13 & 2 & 100 \\
\hline 4 HEs & 8 & 8 & 2 & 6 & 45 & 8 & 0 & 100 \\
\hline 5 PTs & 14 & 13 & 3 & 10 & 38 & 11 & 2 & $95 \cdot 5$ \\
\hline 6 Pharm. & 5 & 5 & 0 & 5 & $35(1 / 3)$ & 5 & 0 & 100 \\
\hline 7 PMWs & 234 & 230 & 94 & 136 & 33 & 230 & 0 & 98 \\
\hline 8 NMSs & 45 & 41 & 17 & 24 & 45 & 41 & 0 & $90 \cdot 5$ \\
\hline Total/Mean & 366 & 356 & 133 & 223 & 35 & 329 & 27 & $96 \cdot 1$ \\
\hline
\end{tabular}

operation for over 5 years. This kind of variation will help in understanding the different attitudes between year 1 and year 5 .

The health personnel of the NLEP in a district consisted of 1 doctor, 2 nurses, 3 nonmedical supervisors (NMSs), 4 health educators (HEs), 5 leprosy paramedical workers (PMWs), 6 physiotherapy technicians (PTs), 7 laboratory technicians (LTs), and 8 pharmacists (Pharm). They formed the total sample population (N: 366), of whom 356 participated in the study (a $96 \cdot 1 \%$ response rate). The reason for a $3.9 \%$ nonresponse was due mainly to their nonavailability during data collection. The other characteristics of the sample population are shown in Table 1.

\section{METHOD OF ASSESSMENT}

The data was collected using an attitude scale developed by the researcher. The subjects in this study were only assessed by means of a questionnaire, which tested the subject's responses to 5 facets of patient-care relationships, which are:

1 a supportive or prejudiced attitude towards patients;

2 a participative or domineering attitude towards patients;

3 their attitude towards handling stigmatizing aspects in leprosy care;

4 a committed or undercommitted attitude to leprosy patient care; and

5 their attitude towards caring for patients from a low socioeconomic class.

These facets are described in detail in the 'Discussion' section of this paper, and were chosen after nondirective interviews and informal group discussions with a spectrum of health personnel, as described by Moser ${ }^{20}$ during a pilot analysis of the NLEP organizational climate by the author (unpublished data). There was also patient feedback in establishing these facets.

The questionnaire contained statements corresponding to each of the 5 facets. The statements, each loaded with 1 facet, were modified according to the job description of the subject interviewed. For example, while testing attitudes towards handling stigmatizing aspects in leprosy care (Facet 4), pharmacists were given a statement regarding medicine dispensing to disfigured leprosy patients, while statements on ulcer care were given to doctors. This was done to make questions more relevant to the work of the person tested. 
The questionnaire was conducted in the interviewer's presence, but it was completed by the interviewee and all results were confidential.

The scoring system for this questionnaire was adapted from the modified Likert scale response of Vasudeva. ${ }^{21}$ It consisted of a 6-point response: strongly agree (SA); agree (A); mildly agree (MA); mildly disagree (MD); disagree (D) and strongly disagree (SD). The 6point response was chosen to eliminate the 'not sure' response, as there were reports that the 'not sure' response can lead to difficulty and controversy in the interpretation of behavioural studies. ${ }^{22}$ The 6-point response system used in this study makes the subject either reject or accept the statement.

We presented 3 of the 5 statements in the questionnaire to imply negative discrimination and the remaining 2 to imply positive discrimination (Table 3). The scoring for the 2 positive statements were: SD-0, D-1, MD-2, MA-3, A-4 and SA-5. The scores to the responses for negative statements were SD-5, D-4, MD-3, MA-2, A-1 and SA-0. The intercorrelation of facets to this variable with other variables was $r=+0 \cdot 002$. The internal consistency of the attitude scale was obtained by correcting $r$ with the KR-21 formula, $r=1 \cdot 00 .^{23}$

Table 2. Coefficient ranking of variables

\begin{tabular}{|c|c|c|c|c|c|}
\hline Number of Variable & $\mathrm{N}$ & Mean & S.D. & $\begin{array}{l}\text { Coefficient } \\
\text { of } \\
\text { variations }\end{array}$ & Rank \\
\hline 1 Skill development & 356 & 3.09 & $0 \cdot 52$ & $16 \cdot 82$ & 1 \\
\hline 2 Autonomy & 356 & $2 \cdot 95$ & $0 \cdot 62$ & $21 \cdot 01$ & 2 \\
\hline 3 Interdepartmental relations & 356 & $2 \cdot 95$ & 0.63 & $21 \cdot 36$ & 3 \\
\hline 4 Skill variety & 356 & $3 \cdot 03$ & $0 \cdot 66$ & $21 \cdot 78$ & 4 \\
\hline 5 Organisational commitment & 356 & $3 \cdot 06$ & $0 \cdot 67$ & $21 \cdot 90$ & 5 \\
\hline 6 Organisational climate & 356 & $2 \cdot 84$ & 0.63 & $22 \cdot 18$ & 6 \\
\hline 7 Technical satisfaction & 356 & $2 \cdot 74$ & $0 \cdot 66$ & 24.09 & 7 \\
\hline 8 Skill utilisation & 356 & $2 \cdot 77$ & $0 \cdot 69$ & $24 \cdot 91$ & 8 \\
\hline 9 Interaction of health professionals with administration staff & 356 & $2 \cdot 49$ & 0.63 & $25 \cdot 30$ & 9 \\
\hline 10 Job significance within the organisation & 356 & $2 \cdot 71$ & $0 \cdot 69$ & $25 \cdot 46$ & 10 \\
\hline 11 Adjustment pattern to the nature of work & 356 & $2 \cdot 43$ & 0.62 & $25 \cdot 51$ & 11 \\
\hline 12 Job significance within the community & 356 & $2 \cdot 57$ & $0 \cdot 68$ & $26 \cdot 46$ & 12 \\
\hline 13 Ad justment pattern to the disease & 356 & $2 \cdot 30$ & $0 \cdot 59$ & $25 \cdot 65$ & 13 \\
\hline 14 Pay satisfaction & 356 & $2 \cdot 70$ & $0 \cdot 72$ & $26 \cdot 67$ & 14 \\
\hline 15 Promotion satisfaction & 356 & $2 \cdot 91$ & $0 \cdot 78$ & $26 \cdot 80$ & 15 \\
\hline 16 Supervisory behaviour & 62 & $2 \cdot 83$ & $0 \cdot 76$ & $26 \cdot 86$ & 16 \\
\hline 17 Health Professionals-leprosy patients relationship & 356 & $2 \cdot 58$ & $0 \cdot 71$ & $27 \cdot 52$ & 17 \\
\hline 18 Subordinates description of supervisors behaviour & 356 & $2 \cdot 39$ & 0.67 & $28 \cdot 03$ & 18 \\
\hline 19 Doctor-Paramedical Relationships & 356 & $2 \cdot 43$ & $0 \cdot 72$ & $29 \cdot 63$ & 19 \\
\hline
\end{tabular}

\section{STATISTICS USED}

(a) The mean of the scores obtained by each person for all the 19 variables was calculated, and the coefficient of variation was computed for priority ranking (Table 2).

(b) A 'two-tail' test was used for analysing the significance of difference in responses between both states.

(c) The overall attitude of the individual professional group was analysed with the assistance of a bar diagram. 
Table 3. Frequency of responses by total sample in each facet

\begin{tabular}{|c|c|c|c|c|c|c|c|c|c|c|}
\hline \multirow{3}{*}{$\begin{array}{l}\text { Facet } \\
\text { no. }\end{array}$} & \multirow{3}{*}{$\begin{array}{c}\text { Bias of } \\
\text { statement }\end{array}$} & \multirow{2}{*}{\multicolumn{7}{|c|}{ Frequency of response }} & \multicolumn{2}{|c|}{ Desirable attitude } \\
\hline & & & & & & & & & \multirow{2}{*}{$\begin{array}{l}\text { Score } \\
>15.0\end{array}$} & \multirow{2}{*}{$\begin{array}{c}\text { Percent } \\
(\%)\end{array}$} \\
\hline & & 0 & 1 & 2 & 3 & 4 & 5 & Total & & \\
\hline 1 & Negative & 49 & 107 & 81 & 40 & 70 & 9 & 356 & 237 & $66 \cdot 57$ \\
\hline 2 & Negative & 42 & 132 & 16 & 26 & 100 & 36 & 352 & 190 & 53.98 \\
\hline 3 & Negative & 33 & 72 & 19 & 54 & 146 & 28 & 352 & 228 & $64 \cdot 77$ \\
\hline 4 & Positive & 31 & 98 & 52 & 18 & 105 & 49 & 353 & 181 & $51 \cdot 27$ \\
\hline 5 & Positive & 158 & 14 & 25 & 3 & 18 & 9 & 355 & 325 & $91 \cdot 27$ \\
\hline \multicolumn{9}{|c|}{ Overall percentage of the total sample with score } & $>15 \cdot 0$ & $65 \cdot 57$ \\
\hline
\end{tabular}

(d) Similarly, the overall attitude of the individual professional group's response to each facet tested was analysed with the assistance of a graph.

\section{Results}

1 The scores obtained for each factor of the questionnaire were totalled. A score of 15 or above was considered to indicate a 'desirable attitude' in the person tested under the presumption that the positive urge overwhelmed the negative inner feelings. The results of such tabulation are shown in Table 3. According to these criteria, $65 \cdot 54 \%$ of the personnel tested had a 'minimum desirable attitude'.

2 An analysis of the responses to each facet shows the lowest range on facet 2 (in Fig. 1, range $20-57 \%$ ) indicating a domineering attitude of health personnel towards their patients, and the highest range in caring attitude towards patients from a low socioeconomic class (range $86-100 \%$ : facet 5 in Fig. 1).

3 Further analysis (Table 2) of 19 work-related attitudinal variables ranked according to the mean score, standard deviation and coefficient of variations show that health professionals' attitude with leprosy patients ranked 17 th in the total of 19 variables $(\mathrm{N}=356 ;$ Mean $=2 \cdot 58 ; \mathrm{SD}=0 \cdot 71$; Coefficient of variations $=27 \cdot 52)$. (The remaining 18 variables are briefly summarized in the 'Introduction' section of this paper.)

4 Overall 'desirable attitudes' in relationships with patients by different health professionals were calculated. Laboratory technicians had the highest score (74.67\%), and the health educators had the lowest score $(57 \cdot 5 \%)$ while the rest of the team members ranged in between (Fig. 2). The PMWs are promoted to NMSs on seniority basis. Both these professional groups shared the same overall attitude towards patients (NMSs $65.85 \%$ and PMWs 65.09\%) (Fig. 2).

5 An analysis of the data was made to discover whether there was a change in attitude over time in both regions, i.e. in the region where MDT had been in practice for 5 years compared to the region where the programme had been initiated only 1 year previously. The analysis was done using the 2-tail test for obtaining the level of significance for the difference between both groups. The results show no such significant difference (Table 4). The quality of the relationship between health personnel and leprosy patients differed only between specialities on the basis of their work, but remained consistent in different regions, and this pattern is still seen even after 5 years. 


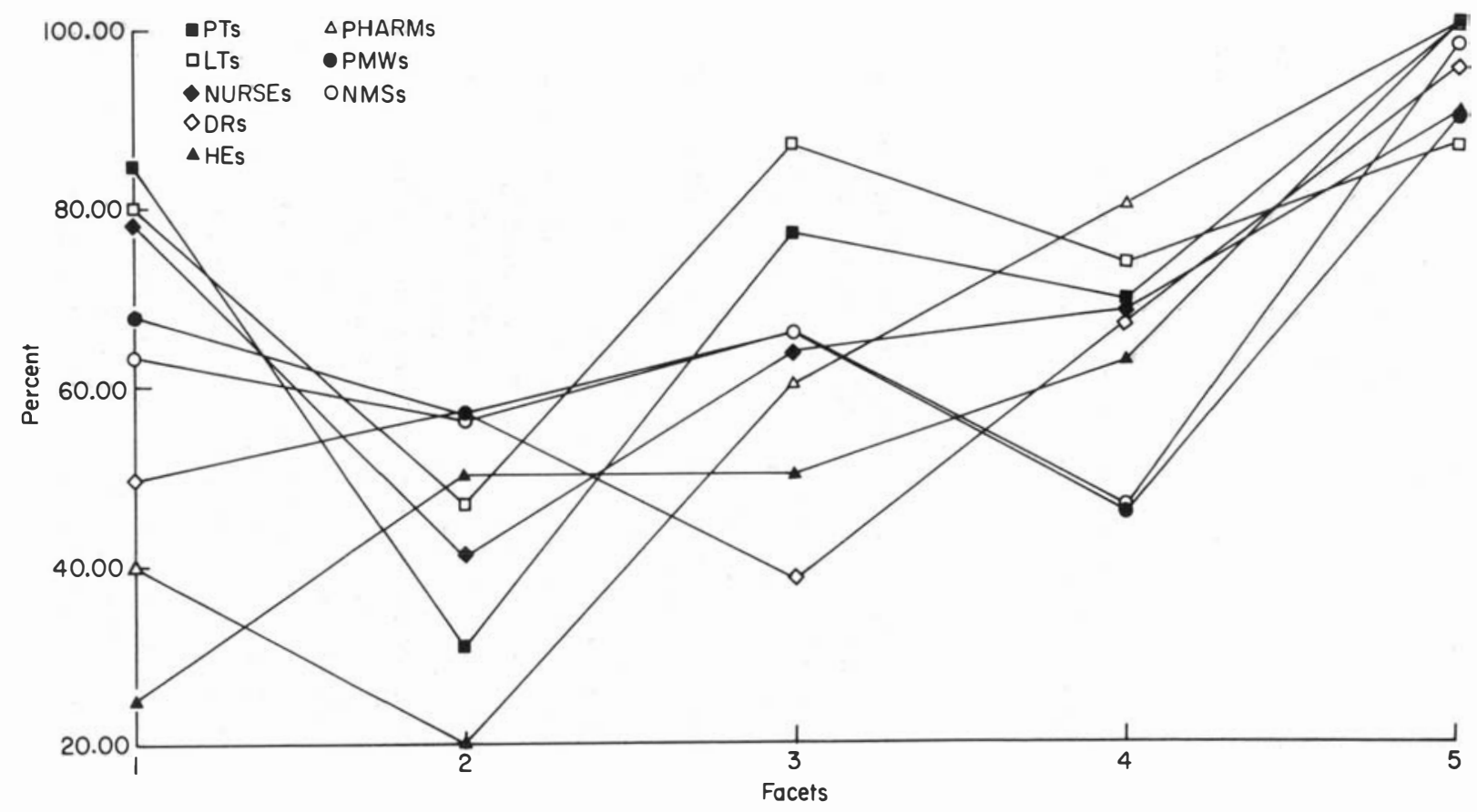

Figure 1. Percentage achieving 'desirable attitude' in each facet. 


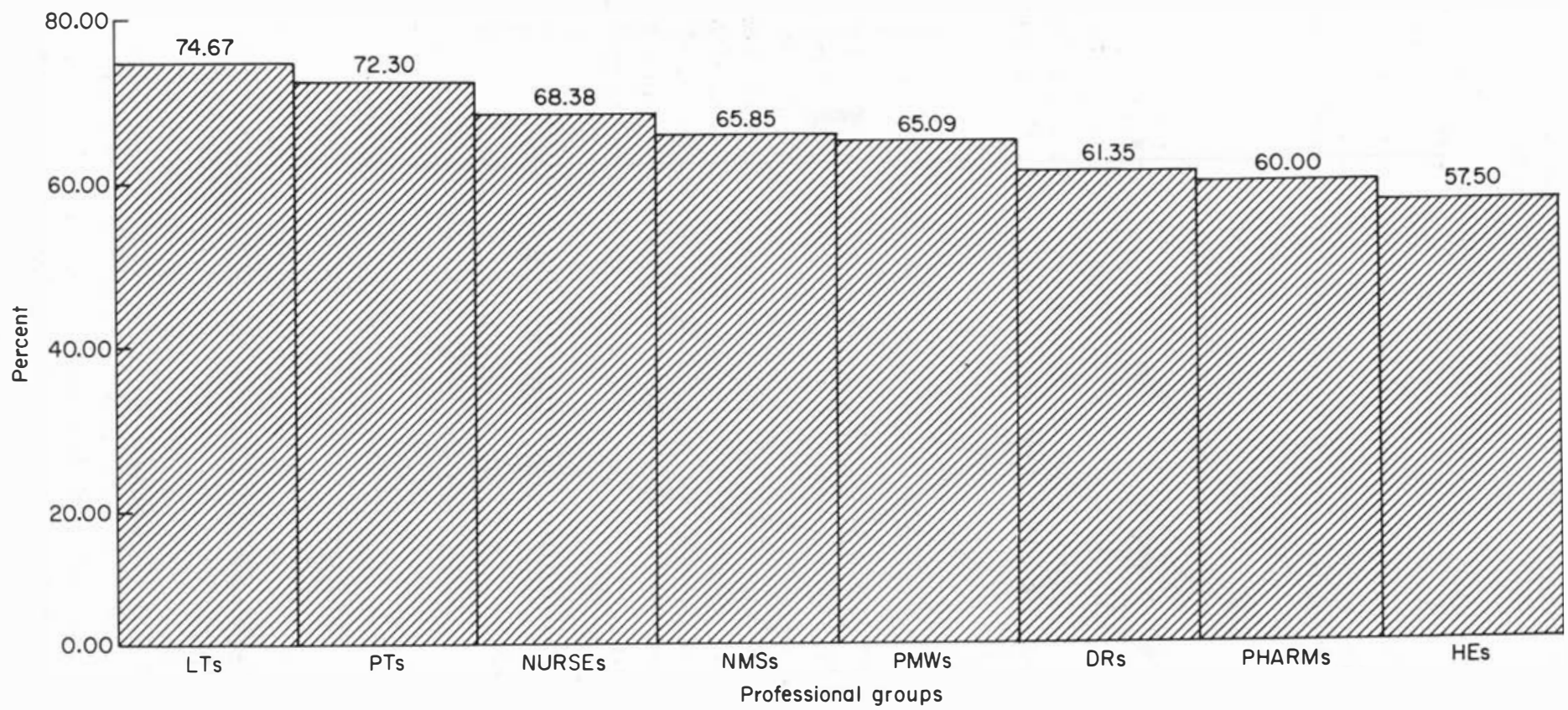

$\frac{1}{3}$

Figure 2. Percentage achieving 'desirable attitude' in total score. 
Table 4. Scores by programme duration

\begin{tabular}{|c|c|c|c|c|c|c|c|c|c|c|}
\hline \multirow{2}{*}{$\begin{array}{l}\text { Duration } \\
\text { of } \\
\text { programme } \\
\text { (years) }\end{array}$} & \multirow[b]{2}{*}{$\mathrm{N}$} & \multirow[b]{2}{*}{ Mean } & \multirow[b]{2}{*}{ SD } & \multirow[b]{2}{*}{ SEr } & \multirow[b]{2}{*}{$F$} & \multirow[b]{2}{*}{$P$} & \multicolumn{4}{|c|}{ Separate variance estimate } \\
\hline & & & & & & & $\mathrm{t}$ & df & $\begin{array}{c}2 \text {-tail } \\
p\end{array}$ & $\begin{array}{c}\text { Significant/ } \\
\text { Not significant }\end{array}$ \\
\hline $\begin{array}{l}1 \\
5\end{array}$ & $\begin{array}{l}133 \\
223\end{array}$ & $\begin{array}{l}2 \cdot 60 \\
2 \cdot 57\end{array}$ & $\begin{array}{l}0 \cdot 660 \\
0 \cdot 740\end{array}$ & $\left.\begin{array}{l}0 \cdot 075 \\
0 \cdot 049\end{array}\right\}$ & $1 \cdot 24$ & $0 \cdot 180$ & $0 \cdot 46$ & $301 \cdot 17$ & $0 \cdot 644$ & N.S. \\
\hline
\end{tabular}

* Significance level of $\mathrm{F}$ value is small. Therefore separate variance 2-tail probability estimate used.

\section{Discussion}

The main finding of this study is that the attitude of two-thirds of the NLEP personnel to their patients is in the 'desirable' range, and one-third is not, which is a significant proportion. It appears that this is the prime reason for the low ranking of the relationship of the health personnel with leprosy patients that appears in Table 2. Based on the results of this study, the pattern of group dynamics experienced by the NLEP is explained as follows:

\section{COMMAND GROUPS}

Careful observation of Table 2 shows that the lower 4 rankings (16-19) are related to interactions between health personnel at the leader-subordinate level, e.g., health personnel with leprosy patients, doctors with paramedical staff and supervisors with subordinates. On the other hand, interdepartmental relationships are observed in the highest ranking rows (1-3). Similarly, the interaction of health professionals with administrative staff is observed in the upper middle ranking rows (4-9). Both these observations indicate that outgroup bias does not adversely affect the interaction between members of different groups within the programme, provided the leader-subordinate relationship does not exist.

\section{PROFESSIONAL GROUPS}

An analysis of each facet based on the performance of each professional group has been used to compare their attitude within and across the groups. The findings are as follows:

\section{Supportive or prejudiced attitude}

A supportive attitude is the inclination of the team to understand the emotional (affective) disposition of the patient, e.g., anxiety, depression and anger, and the willingness to show empathy. A prejudicial attitude is the failure to appreciate the patient's emotional problems.

Physiotherapy technicians had the highest supportive attitude while nurses were third on the list. By the nature of their work, these professionals have a limited number of patients to take care of per day and they spend more time with individual patients compared to all the other professionals in this study. Because of the chronic nature of these deformities (e.g. recurrent ulcers), the same patients are seen and known by these 
personnel over a period of several years, therefore a better rapport is developed with these patients and, because the patients are aware of the chronic nature of their deformities, there is little or no pressure by these patients on the personnel to cure these deformities within a specific period of time, so the patient population shows less aggressiveness to these personnel. Laboratory technicians also scored very highly in this factor, despite the fact that they have very limited opportunity to interact with patients.

\section{Participative or domineering attitude}

If health personnel allow the patient some leeway to decide on his treatment procedure, it indicates a participative attitude. Expecting a patient to think and act exactly as the health professional does, indicates a domineering attitude. This study demonstrates that this is the only facet in which most of the team members have scored low (Fig. 1), indicating that a domineering attitude towards patients is significantly high.

The organization itself is perhaps the cause of it. In the NLEP, antileprosy care is given free; a seller-customer type of interaction does not take place when treatment is given free and this places the patient more at the mercy of various health personnel. Such a situation can easily lead to a considerable number of health workers adopting an authoritarian attitude. It is interesting to note that doctors, the team leaders, had a much less domineering approach than the personnel of all the other deciplines. Professional ethics are emphasized more in medical education than in the other 6 disciplines researched in this study, resulting in a better inculcation of these ethics to their professional life.

\section{Attitudes in handling the stigmatizing aspects in leprosy care}

Societies' aversion to leprosy and its deformities have been documented in the past. ${ }^{1-4}$ The analysis of this facet of the study was to determine whether or not the multidisciplinary team shared the same negative feelings.

The results demonstrated that while $50 \%$ of allied health professionals did not share this aversion, approximately two-thirds of the doctors did. The historical reasons for fear about leprosy cannot be the cause of this as doctors are more aware of the rational scientific facts of leprosy than the allied health personnel.

A study has proved that from a very early stage in their education, medical students possessed a conservative attitude towards certain issues, ${ }^{24}$ and another study has demonstrated that doctors have unrecognized prejudices about chronic illnesses because they are not easily curable. ${ }^{25}$ Deformities in leprosy are chronic in nature and it is not surprising that doctors working in leprosy may have an unrecognized prejudice. Another study stated that the medical profession may hold attitudes and values which are representative of only a minority of society. ${ }^{26} \mathrm{It}$ is derived from empirical evidence which shows that physicians are mainly drawn from a narrow stratum of the population. This study pointed out that medical students in Britain are almost exclusively drawn from the Registrar General's Social Classes 1 and 2 (that is mainly the business and professional classes), while most of their patients are likely to come from social class 3 to 5 (composed mainly of manual workers). ${ }^{26}$ However, how this relates to the situation in India has not been established. If these facts are relevant to the Indian situation it demonstrates that the stigma is high among doctors in comparison to the rest of the specialities despite progress and change in medical knowledge. 


\section{Committed or undercommitted attitude}

The commitment of the team members refers to an effective attachment to the kind of job the personnel are doing. Bijleveld ${ }^{7}$ stated that there was a lack of commitment among the PMWs in many countries. This statement still holds good for PMWs and NMSs, as is demonstrated by this study when the scale of overcommittedness to undercomittedness is applied (facet 3 in Fig. 2).

Interestingly, PMWs and NMSs are highly rewarded groups of workers in terms of monetary benefits and promotions, ${ }^{16,17}$ and their self-image has significantly increased from its rather low status in the 60 s to that of a moderate status job. ${ }^{16,17}$ The job description of PMWs includes demanding activities, such as preclinic drives, taking the patients to the clinics, keeping patient absenteeism at the clinic at the lowest level possible, screening the general public and schoolchildren for leprosy, and record work. The senior PMWs are promoted to NMSs and they supervise the abovementioned activities of the PMWs.

Their working hours are in the very early or latter part of the day, so the work characteristics and environment are stressful. A study has shown that individuals who work in stressful and demanding situations may develop emotional exhaustion. ${ }^{27}$ In turn, this may be the cause of a less committed attitude. Both these professional groups form the largest number of team members in the NLEP (Table 1) and as they have responsibility for the major share of leprosy control activities, ${ }^{28}$ their commitment to their work must be enhanced.

\section{Caring for patients from a low socioeconomic class}

Leprosy patients are mostly from the lower socioeconomic and educational classes. ${ }^{29}$ Earlier studies have shown that different socially disadvantaged groups, like women and black patients, receive inferior care to that provided for their respective counterparts. ${ }^{30}$ This is not the case now in leprosy (facet 5 in Fig. 1). However, the abovementioned study was done in a general hospital where multiracial groups were treated, whereas this study was carried out in a vertical programme in which only leprosy patients were treated, so a further study is essential in an environment where leprosy is treated along with other diseases. Nevertheless, this result illustrates that almost all the professional groups (86$100 \%$ ) had no problem in caring for patients from a low socioeconomic class (facet 5 in Fig. 1). It certainly reveals that leprosy personnel do understand more about the social and cultural differences between themselves and their patients.

\section{Acknowledgment}

This study is a part of the doctoral and private study of R. Premkumar that was accepted by the Faculty of Social Sciences, Nagpur University, Nagpur, India. We wish to thank the Data Processing Unit staff of SLR \& TC, Karigiri, for their statistical and secretarial assistance and Mr C. Chong, Data Analyst of the TLM-SE Asia Evaluation Unit for the figures. We are also thankful to Dr J. R. Burslem, Dr S. Suneetha, Dr S. Gokavi and Mr $D$. Tenant for their assistance in preparation of this manuscript. 


\section{References}

${ }^{1}$ Elissen MCCA, Harms MAM. South Sulawesi (Indonesia) illness beliefs of leprosy patients. Project Report of Medical Students at the University of Amsterdam, the Netherlands, 1989, 10.

2 Gussow Z, Tracy GS. Stigma and the leprosy phenomenon: the social history of a disease in the nineteenth and twentieth centuries. Bulletin of Historical Medicine, 1970; 44: 425-449.

${ }^{3}$ Mohammed HAA. Leprosy—the Moslem attitude. Lepr Rev, 1985; 56: 17-21.

${ }^{4}$ Neylan TC, Nelson KE, Schauf V, Scollard DM. Illness beliefs of leprosy patients: use of medical anthropology in clinical practice. Int J Lepr 1988; 56: 231-237.

${ }^{5}$ Huikeshoven $\mathrm{H}$, Bijleveld I. Encouraging results from DDS urine analysis among registered leprosy patients in the Wangas, Kenya; an exception that challenges the rule. Lepr. Rev. 1978; 49: 47-52.

6 Bijleveld I. Leprosy care; patients' expectations andexperience. A case study in western province, Kenya. Royal Tropical Institute, Amsterdam, the Netherlands, 1977.

7 Bijleveld I. Who says leprosy patients are ashamed or lazy? Sasakawa Report on the 3rd International Workshop on Leprosy Control in Asia. Taipei, Taiwan, 1980; 17-25.

${ }^{8}$ Kumar A, Thangavel N, Durgambai K, Sirumban P. Medical care throiugh leprosy clinics-consumer's perception, experiences and suggestions. Ind J Lepr, 1985; 57: 845-861 .

9 Kumar A, Anbalagan M. Illness and service utlization behaviours of leprosy patients. Lepr. India, 1982; 54: 338-347.

10 Kumar A, Anbalagan M. Socio-economic experiences of leprosy patients. Lepr India, 1983; 55: 374-381.

11 Premkumar R, Dave SL. Professional freedom and government health personnel. Unpublished report.

12 Vijayalaxmi B, Ramana K. A study of job satisfaction, job commitment and attitude towards patients of paramedical workers in the field of leprosy. Ind J Lepr, 1988; 60: 510-516.

13 Awof eso N. Appraisal of the knowledge and attitude of Nigerian nurses towards leprosy. Lepr Rev, 1992; 63: 169-172.

14 National Leprosy Eradication Programme in India, Facts and Figures on Leprosy. Tech. Rep. Ser. of Leprosy Division, DGHS, Ministry of Health and Family Welfare, New Delhi, 1987.

15 Premkumar R, Dave S. Relationship problems between doctors and paramedical professionals working in leprosy with reference to a possible solution. Lepr Rev, 1992; 63: 173-182.

16 Premkumar R, Suneetha S, Dave SL. Pay-promotion-prestige and the health personnel in Hansen's Disease. The Star, 1993; 52: 7-9.

17 Premkumar R, Suneetha S. Leprosy workers. World Health Forum. 1993; 14: 293-4.

18 Premkumar R, Dave SL. Impact of multidrug therapy on health personnel in their level of job satisfaction. Ind J Lepr, 1993, 65: 4th issue.

19 Heszen-Klemens I. Patients' noncompliance and how doctors manage this. Social Science Medicine, 1987; 24: 409-416.

20 Moser CA. Survey Methods in Social Investigation. Heinemann, London, 1958.

21 Vasudeva P. Social change. An analysis of attitudes and personality. Sterling Publications, New Delhi, 1977.

22 Woodworth RS, Schlosberg H. Experimental psychology. Methuen, London. 1955.

${ }^{23}$ Kurt AK, Mayo ST. Statistical method in education and psychology. Narosa Publishing House, New Delhi, 1980.

${ }^{24}$ Ewan CE. Attitude to social issues in medicine: a comparison of first year medical students in non-medical faculties. Medical Teacher, 1987; 21: 25-31.

25 Wainpal SF. The physically disabled and the physicians. JAMA, 1987; 257: 2935-8.

${ }^{26}$ Hart TC. Sociology of Medical Practice. Collier-Macmillan, London, 1975.

27 Leiter MP. Burnout as a function of communication patterns. Group and Organisational Studies, 1988; 23: 111-128.

28 Reddy JVS. Health and human resource mobilization: an assessment of staffing pattern in NLEP at operational level. Ind J Lepr, 1993; 65: 81-93.

29 Noordeen SK. The epidemiology of leprosy. Chapter 2. In Leprosy. Hastings RC. (ed). Churchill Livingstone, London, 1985, 21-22.

30 Egebert LD. Relationship between race and economic status of patients and who performs their surgery. $N$ Engl J Med, 1977; 97: 90-91. 


\title{
Comment comprendre l'attitude envers leurs malades des équipes multidisciplinaires travaillant sur la lèpre?
}

\author{
R. Premkumar, K. Satish Kumar et S. L. Dave
}

Résumé Cette étude examine l'attitude envers leurs malades lépreux du personnel de santé travaillant pourle programme national d'éradication de la lèpre (NLEP) aux Indes. Ce personnel a été étudié individullement et par groupes homogènes de façon à permettre les comparaisons à l'intérieur du groupe et entre les groupes, et, d'autre part, entre les groupes de différentes régions poursuivant des programmes de santé similaires, pendant des périodes allant de 1 à 5 années.

L'échantillon de population était constitué d'employés du NLEP de 2 gouvernements d'état, soit 8 groupes de personnel de santé. Nous avons établi un questionnaire pour chacun de ces groupes pour obtenir des informations sur 5 aspects de leur relations avec leurs malades.

La principale observation a été que les deux tiers du personnel examiné possédaient le 'minimum désirable' d'interéaction avec leurs malades. La qualité de leurs relations variait seulement avec les spécialités du travail, mais restait constante dans la même spécialité dans des régions différentes; ce tableau n'avait pas changé après 5 ans d'un programme de thérapeutique multidrogue (MDT). Une analyse supplémentaire a montré que, bien que le personnel ait une attitude attentionnée envers les malades des classes sociales inférieures, une attitude opprimante envers ces mêmes malades était également répandue. L'analyse par spécialité a révélé que les techniciens de laboratoire arrivaient les premiers pour 'l'attitude désirable' (74,67\%) et les éducateurs de santé les derniers $(57,5 \%)$, le reste de l'équipe se plaçant entre les deux. Le préjudice contre la lèpre était plus fort chez les médecins que chez les autres membres de l'équipe.

La discussion est basée sur les performances, globales et dans chacune des 5 facettes de l'enquête, de chaque groupe avec référence à leur rôle professionnel et aux études similaires menées auparavant.

\section{Comprendiendo la actitud de los equipos multidisciplinarios a sus pacientes leprosos}

\author{
R. Premkumar, K. Satish Kumar y S. L. Dave
}

Resumen Este estudio investigó la actitud a sus pacientes leprosos del personal de sanidad que trabaja en el Programa Nacional para la Eradicación de la Lepra (NLEP), en India. Se estudió el personal, como individuos o en grupos homogéneos para poder ef ectuar comparaciones en y entre grupos, y entre los grupos de regiones dif erentes que realizaban programas similares, con una dif erencia de duración de entre 1 y 5 años.

La muestra de la población fue los empleados del NLEP de 2 gobiernos de estado consistiendo de 8 grupos de profesionales de sanidad. Se desarrolló un cuestionario para cada uno de estos grupos para extraer información sobre 5 aspectos de sus relaciones con sus pacientes.

El resultado principal del estudio fue que dos tercios del personal examinado tenía la interacción 'mínima deseable' con sus pacientes. La calidad de sus relaciones dif ería según la especialización de su trabajo, pero era unif orme para la misma especialización en regiones dif erentes; esta conclusión permaneció constante después de 5 años de un programa multidroga (MDT). Un análisis posterior indicaba que tenían una actitud humanitaria a las clases socio-económicas bajas, y al mismo tiempo una actitud dominante a los mismos pacientes. Un análisis que tomaba en cuenta la especialización reveló que los técnicos de laboratorio tenían la 'actitud deseable' más elevada $(74,67 \%)$, y los educadores de sanidad tenían la más baja $(57,5 \%)$, y los demás miembros del equipo presentaban un valor intermedio. El estigma hacia la lepra fue mayor entre los médicos que entre los demás miembros del equipo.

La discusión está está basada en la actuación, total y dividida en 5 características, de cada uno de los grupos profesionales con referencia al tipo de trabajo y a los estudios similares realizados antes. 